This Journal is available in Telkom University online Journals

Jurnal Manajemen Indonesia

\title{
Importance and Contents of Business Plan: A Case-Based Approach
}

\author{
Ruqayah Abdullah \\ University of Miami, Coral Gables, Florida, United States
}

\begin{abstract}
Planning and business plan, as its product represent essential part of the overall business management. The business plan covers all important aspects of the business and the key factors that affect its performance. The business plan is used to increase the opportunities for development, growth and raise additional capital. This paper discusses the importance of business plan, its contents and provides some rules that should be taken into consideration during its writing, etc. In this paper is used the case-based methodology, where a practical example of a business plan is provided. The paper ends with discussion and conclusion section and limitations, practical implication and future research avenues as well.
\end{abstract}

Keywords-Planning, Business Plan, Eentrepreneur, Marketing, Capital

\begin{abstract}
Abstrak
Perencanaan dan rencana bisnis, sebagai produknya merupakan bagian penting dari manajemen bisnis secara keseluruhan. Rencana bisnis mencakup semua aspek penting bisnis dan faktor kunci yang mempengaruhi kinerjanya. Rencana bisnis digunakan untuk meningkatkan peluang pengembangan, pertumbuhan dan penambahan modal. Makalah ini membahas tentang pentingnya business plan, isinya dan memberikan beberapa aturan yang harus dipertimbangkan selama penulisannya, dll. Dalam makalah ini digunakan metodologi berbasis kasus, dimana disediakan contoh praktis dari business plan. Makalah ini diakhiri dengan diskusi dan bagian kesimpulan dan batasan, implikasi praktis dan jalan penelitian masa depan juga.
\end{abstract}

Kata kunci — Perencanaan, Rencana Bisnis, Pengusaha, Pemasaran, Modal

\section{INTRODUCTION}

Utami and Triady (2019) noted that current business condition is highly dynamic, with various turbulences occurred and changes are inevitable to be faced by companies and their people. These circumstances require from entrepreneurs to be more innovative in doing business and planning their activities in a prudent manner. Planning is the primary function of management. It represents the basis for other managerial functions, such as organization, coordination, motivation and control. Planning reduces uncertainty by anticipating changes. It urges entrepreneurs to look ahead, anticipate changes, think about the shocks of these changes, and prepare adequate responses. Planning enables and helps to reduce and eventually avoid the phenomena and activities that can lead to destruction.

Theoretical and empirical research proves that small business owners rarely use planning in their work. With the help of planning they will have the opportunity to solve a significant number of problems and barriers that arise during the operation of the enterprise. Every aspect of business activity should be analysed, such as marketing, production, financing, staffing, business risk, market research, products - services, competition, economic trends, etc. (Anggadwita and Yuuhaa, 2014). Analysing these aspects would enable you to gain a clearer picture of small business. In addition to business policy and goals, the final product of the planning process is the plan.

The aim of this paper is to present the importance of the business plan for the entrepreneurs, and its contents and presentations' suggestions as well. Business plan is one of the most important documents of the enterprise.

\author{
Article info \\ Received (14/12/2019) \\ Revised (02/05/2020) \\ Accepted (30/06/2020) \\ Corresponding author: rxa709@miami.edu \\ DOI: 10.25124/jmi.v20i2.3204 \\ Copyright@2020. Published by School of Economics and Business - Telkom University
}


Prior to the establishment of the enterprise, the entrepreneur must design a business plan, which includes the following elements: the scope of action, the type of product or service to be produced or offered, the volume of planned activities, the expected profit, competition, capacity of the enterprise, location, necessary and similar cadres. In addition to the usual business plan, the entrepreneur should also design an investment plan to provide the necessary financial resources from potential investors. The business plan is the basis for obtaining loans from banks. In the end, the business owner needs to come up with something out of the ordinary. Lack of adequate planning is one of the main reasons for the failure of small businesses (Scarborough and Cornwall, 2018).

This paper is divided in several sections. After the introduction section, comes the literature review section, where are presented some definitions of business plan, its importance, contents of business plan and some rules to be taken into consideration during its writing, etc. In third section is provided a practical example of a business plan. The paper is end with the conclusion section.

\section{LITERATURE REVIEW}

\section{A. Definition and importance of business plan}

In the literature can be found several definitions about the business plan. Some of these definitions and explanations are summarized in Table 1. Based on these definitions, can be concluded that the business plan presents a written document, which describes in detail the business vision, mission and goals, the necessary financial, material and human resources and the development strategies as well.

Table 1. Definitions and explanations of business plan

\begin{tabular}{ll}
\hline \multicolumn{1}{c}{ Author (s) } & \multicolumn{1}{c}{ Definition and explanations } \\
\hline $\begin{array}{l}\text { Hisrich and Ramadani } \\
\text { (2017, p.19) }\end{array}$ & $\begin{array}{l}\text { "A key aspect of developing a strategy at each level (the enterprise level, the } \\
\text { corporate level, the business level, the functional level, and the sub-functional } \\
\text { level) is establishing goals and objectives. Goals need to be challenging and yet obtainable with } \\
\text { effort. They need to be measurable so that the results can be evaluated and performance } \\
\text { appraised. In order to accomplish the goals established and implement the strategy, a business } \\
\text { plan is often created as it is an effective tool for providing the direction to the entrepreneur." }\end{array}$ \\
"A business plan is also a road map that provides directions so a business can plan its future \\
and helps it avoid bumps in the road. The time you spend making your business plan though \\
and accurate, and keeping it up-to-date, is an investment that pays big dividends in the long \\
and (2020)
\end{tabular}

An entrepreneur needs a written business plan for several reasons. Among the main reasons for designing and possessing a written business plan are the following (Genadinik, 2019; Hisrich, Peters and Shepherd, 2020, 2017):

1. To be committed to the business. The most important stakeholder of any business is the founder himself. The first and most important thing is to convince yourself that starting a private business is a good and fair thing for you, both personally and in terms of investment.

2. To get funds from banks. Until the late 1980s, in the United States, designing a business plan to get funds from banks was just an option for the entrepreneur. Banks estimated that the business plan helped to create a better picture for the enterprise but was not a relevant component in making decisions about whether or not to lend. After the failure of the banks, in the late 80s and early 90s, they changed this approach. Banks were placed under a stricter supervision and audit by the state, and as a result, during 
each loan application they required entrepreneurs to write a business plan, which became part of the marketing campaigns organized by the banks.

3. To attract investors. For years, the business plan has become an "entry ticket" in the process of assessing enterprises by venture capitalists, regardless of whether they are formal or informal (private investors). Rare are the investors who can make a decision to invest in an enterprise just from the presentation. Even if you manage to "sell" your idea, you will later be required to provide the same in writing, respectively to write the business plan.

4. For preparation of strategic alliances. Research, marketing and other joint ventures between small and large enterprises have become common practice in recent years. These efforts, known as strategic alliances, are as the result of the common needs of small and large enterprises. Small businesses need financial resources, while large ones need innovations. Many small businesses in the early stages of their development are looking for alliances with large corporations. To make the choice easier, corporations request a written business plans from small businesses. The most preferable for corporations are those small businesses that by themselves offer business plans without asking it by the corporations.

5. To win large contracts. When small businesses are looking for long-term cooperation (often supply) contracts, corporations often respond arrogantly: "Everyone knows who we are. But no one knows who you are! How will you? Do we know that you will exist after 3 or 5 years and will you supply us with the necessary parts or services for our products?" If in this situation, entrepreneurs are willing to offer them business plans, they will surely impress them, as they will give them clear signals that this small enterprise is sincerely thinking about its future, respectively will tell corporations that they think they exist in 3,5 and many years into the future and will be much more powerful than they are today.

6. To attract quality workers. One of the biggest problems of small inter-enterprises is attracting quality workers and convincing them to take the risk that this enterprise will exist in the future and grow over the years. The best cadres still retreat from large corporations. Small business should be just as convincing as corporations in this regard. A well-written business plan will convince them that entrepreneurs have anticipated all the major business issues as well as how to manage them. The business plan will also help future workers become familiar with the culture and rationality of doing business. He will convince them that only the best, the most compatible, will get the job.

7. To complete mergers and acquisitions. No matter which side of the conversation you may be on, the business plan can help you in this process. If you want to sell your business, the business plan will allow you to enter this process faster and clearer, making it easier for both, you and the buyer, to evaluate the business. The business plan informs potential accusers that you have thought about the future of the business, as well as how and where to take it. If you want to join another company, through the business plan you will prove that you will be a serious partner in the future.

8. To motivate and focus the management team. As small company grow and become more complex in the future, the business plan becomes a very important component to maintain the focus of employees on the goals of the business. The process of designing a business plan helps everyone think about the long-term goals of the enterprise. It represents a reflection of the future for them, until its eventual revision.

Considering these reasons why we should have a written business plan, it can be concluded that the list of users of information from it can be quite long. However, attention is usually paid only to primary users of the business plan, such as (Byrd and Megginson, 2009; Gumpert, 2000):

a. The business owners would mostly like to know those parts of the business plan that have to do with the development plans of the company, where they would also focus their efforts, anticipate the problems and challenges in the future and would provide the necessary measures to deal with them;

b. Workers are interested to know about their benefits from growth and positive results from the activity of the enterprise;

c. Creditors, who assess the credit risk and must approve the same, are more interested in those elements of the business plan that contain information on the cash flow, future revenues and potential profits from the operation of the small company;

d. Investors, on the other hand, are most interested about the break-even point, the rate of return on investment, or the long-term potential of the investment in which they are planning to invest; 
e. Suppliers need information related to the products and services that the company will produce and based on that to provide the necessary raw materials for the production and delivery of those products and services;

f. Consumers want to be informed more about the products and services that new company will offer to the market and what is their difference with those products and services already offered by others and which needs and desires will be met by them.

In the literature and practical examples are presented several variations of business plans regarding its contents, but most of business plans have almost the same elements. These elements are usually grouped into three main general sections, as indicated in Table 2.

Table 2. Contents of a Business Plan

\begin{tabular}{|c|c|c|}
\hline Section 1: & $\begin{array}{l}\text { Title Page } \\
\text { Table of Contents } \\
\text { Executive Summary }\end{array}$ & \\
\hline Section 2: & $\begin{array}{l}\text { Description of Business } \\
\text { Description of the Venture } \\
\text { Product(s) and/or Service(s) } \\
\text { Type of Industry } \\
\text { Mission Statement } \\
\text { Business Model } \\
\text { Description of Industry } \\
\text { Future Outlook and Trends } \\
\text { Analysis of Competitors } \\
\text { Industry and Market Forecasts } \\
\text { Technology Plan } \\
\text { Description of Technology } \\
\text { Technology Comparison } \\
\text { Commercialization Requirements } \\
\text { Marketing Plan } \\
\text { Market Segment } \\
\text { Product or Service } \\
\text { Pricing } \\
\text { Distribution } \\
\text { Promotion } \\
\text { Financial Plan } \\
\text { Sources and Applications of Funds Statement } \\
\text { Pro Forma Income Statement } \\
\text { Pro Forma Cash Flow Statements } \\
\text { Pro Forma Balance Sheet } \\
\text { Break-even Analysis }\end{array}$ & $\begin{array}{l}\text { Production (Outsourcing) Plan } \\
\text { Manufacturing Process (Amount Subcontracted) } \\
\text { Physical Plant } \\
\text { Machinery and Equipment } \\
\text { Suppliers of Raw Materials } \\
\text { Outsourcing Aspects } \\
\text { Organizational Plan } \\
\text { Form of Ownership } \\
\text { Identification of Partners and/or Principal } \\
\text { Shareholders of } \\
\text { Management-Team Background } \\
\text { Roles and Responsibilities of Members of } \\
\text { Organization } \\
\text { Organizational Structure } \\
\text { Operational Plan } \\
\text { Description of Company's Operation } \\
\text { Flow of Orders and Goods } \\
\text { Exit Strategy } \\
\text { Summary }\end{array}$ \\
\hline Section 3: & \multicolumn{2}{|l|}{$\begin{array}{l}\text { Appendices (exhibits) } \\
\text { Exhibit } \mathrm{A} \text { - resumes of principals } \\
\text { Exhibit } \mathrm{B} \text { - market statistics } \\
\text { Exhibit } \mathrm{C} \text { - market research data } \\
\text { Exhibit } \mathrm{D} \text { - competitive brochure } \\
\text { Exhibit } \mathrm{E} \text { - competitive price lists } \\
\text { Exhibit } \mathrm{F} \text { - leases and contracts } \\
\text { Exhibit } \mathrm{G} \text { - supplier price lists }\end{array}$} \\
\hline
\end{tabular}

Source: Hisrich and Ramadani (2017, p.22) 


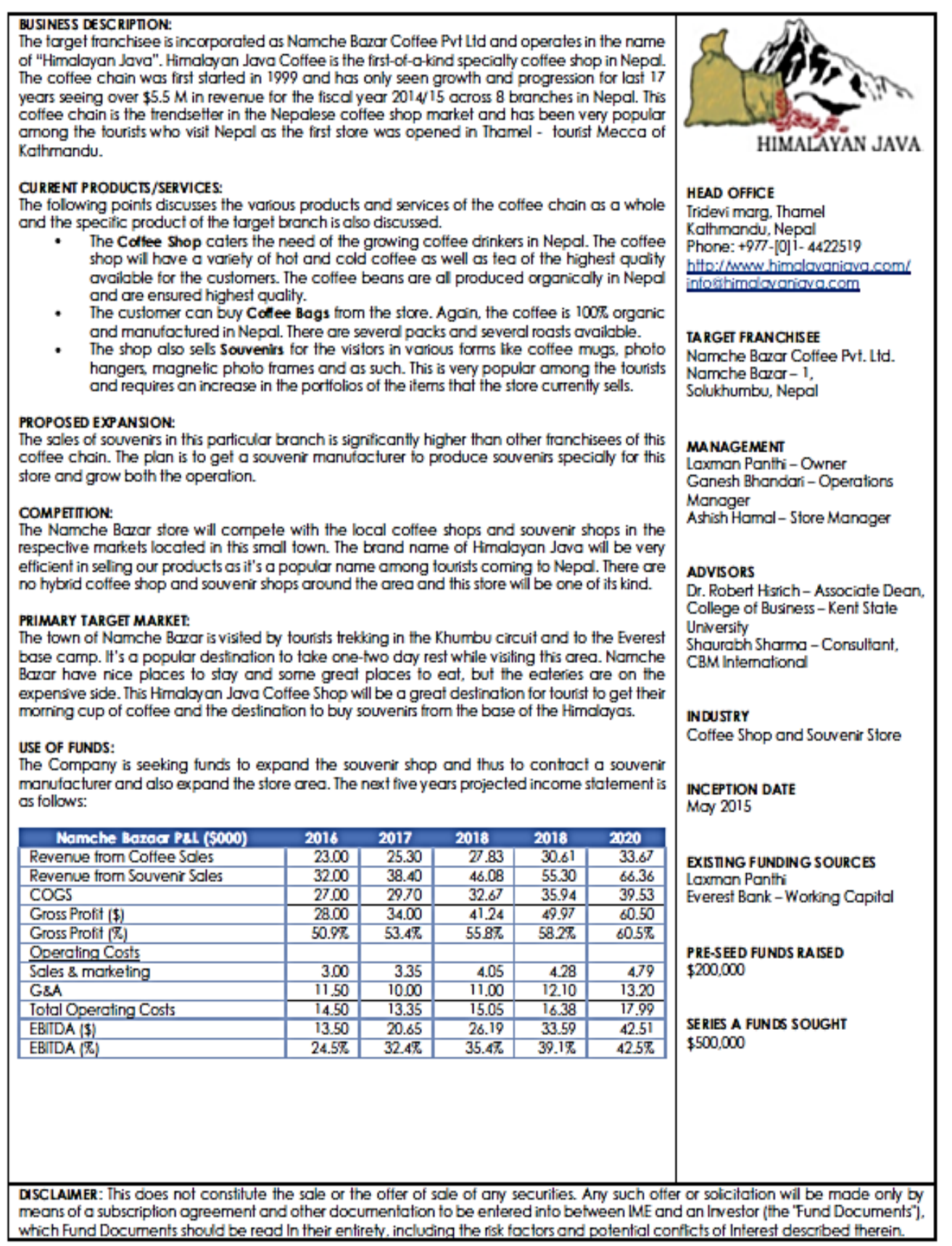

Figure 1. Example of business plan executive summary (Panthi, 2017, p.24)

Beside other elements, the executive summary is a very important part of the business plan. The executive summary, although is one of the first elements, it should be written the last. It presents summaries of the entire business plan synthesized in 1-2 pages, after the other parts have been written. It is important to include the most essential and attractive things in these pages, in order to attract the reader's attention, respectively to increase his curiosity to continue reading on further pages. It usually includes vision, mission and business goals, benefits for the enterprise and stakeholders from the implementation of the plan, advantages of the enterprise over competition and strategies for dealing with it, targeted markets and sales and profit projections, the needed amount of money, key financial indicators, sources of financing and debt repayment plans to banks and other institutions, as well as the amount of money required by banks and investors. So, all of these should be briefly described, as they are presented in detail in the other elements of the business plan as presented in Table 1 . In Fig. 1 is presented an example of modern executive summary. 


\section{Manual for writing a business plan}

In order the business plan's reading and implementation be more effective and attractive, several rules should be taken into consideration during its designing (Kuratko, 2020):

1) The plan should be short. Business plan readers are important people with big commitments and do not have much time to waste. Therefore, the entrepreneur must explain his business activity clearly, precisely and concisely. Around 25-30 pages is acceptable.

2) The plan should be organized in the right way. Content overview, executive summary, attachments, tables, graphs, logical order of plan's components, and overall compatibility are critical elements of business plan presentation.

3) The plan should be future-oriented. The entrepreneur should make an effort to arouse interest by presenting trends and forecasts, which show what the business aims to be and what its future development opportunities are?!

4) Escape from exaggerations. Potential sales, estimated revenues, potential business growth should not be exaggerated. Documentation and research are vital in ensuring the credibility of the plan.

5) Main risks. Business main risk segment represents an important component and demonstrates the owner's ability and willingness to analyse potential problems and provide alternatives to overcoming or resolving them.

6) Features of the management team. In the business plan segment, where the management team is described, the skills of each staff should be clearly identified, with special emphasis on the ability and willingness of different people to work effectively together as a team.

7) Focused. The plan should be focused on a single business opportunity. The new business should not create multi-markets or multi-activities, as long as it has not developed a specific market or activity.

8) Identification of the main market. The entrepreneur needs to identify his/her real customers. Market research plays an important role here, as it provides information about what the consumer is looking for.

9) Formulate the plan in the third person. Instead of often emphasizing "I", "we", or "me" and "us", the business owner should use "he/she", "they" or "them", because in that way the entrepreneur will not be personalized with the plan.

10) Maintain the reader's interest. Investors and creditors accept many business plans, but only a few receive the necessary funds. The entrepreneur should offer something interesting to increase the reader's curiosity. In this context, the cover and executive summary of the business plan play important roles in attracting the reader.

\section{Presentation of business plan}

The presentation of the business plan is as important as its writing. Joseph Mancuso, one of the most wellknown authors who have written about the design and presentation of the business plan, says:

"A good business plan is written for a minimum of five months, but you need five minutes to convince the reader not to throw it in the trash." (Byrd and Megginson, 2009, p.149)

During the presentation an optimal mix between the text and the graphs, tables and photographs should be taken into consideration. Answering the questions below might provide fruitful directions for the presentation of the business plan (Hisrich and Ramadani, 2017):

1) Does the presenter believe in the business plan he presents? If not here's a new product just for you!

2) Are all the necessary facts are supported in the business plan?

3) What are the most powerful arguments of the business plan?

4) What are the special benefits for business plan users?

5) Who else is affected by the activities envisaged by the business plan and have they been taken into account?

6) Why should the current situation change?

7) Are there alternatives to the activities provided by the business plan? Are there any additional options?

8) What arguments are against the business plan? If there are any, they should not be ignored during the presentation.

9) What does the presenter know about the "public", its preferences, interests and peculiarities?

10) Has the time required for the presentation been determined and measured well? 
11) How to summarize the main points of the presentation?

12) How to conclude and achieve the goals set before the presentation?

13) Is the presenter willing to answer questions, especially those he is most afraid of?

If the entrepreneur has the right answers to these questions, he or she is more likely to achieve the goals set before the presentation. From the presentation it may depend on whether it can convince creditors to approve the required loan, or investors to invest their financial means in the business described in the plan. Therefore, everyone should be more than careful when deciding to present their idea to the public of the business plan.

\section{RESEARCH METHOD}

In this case is used the case-based approach. According to Dana and Dana (2005), using case studies "involves the thorough study, in depth and detail, of a limited number of objects, individuals or environments" (p.83). So, in this paper, we have used a case of Secure Co, which is an in-depth business pan which can help entrepreneurs, especially the young ones to develop their own business plans.

\section{Elevator Pitch}

Hello there, my name is Ruqayah and I'm helping businesses flourish while keeping our society safe. One of my greatest passions is providing simple solutions to unsolved problems. I'm fortunate enough to be able to decrease car accidents through my product. Have you ever heard of a driving wheel sensor?

\section{How does it work?}

Simple. The sensor will sense that the drivers' hands are not on the wheel and will start to beep until the driver gets their hands back on the wheel.

\section{$\operatorname{Problem}(s)$ Solved}
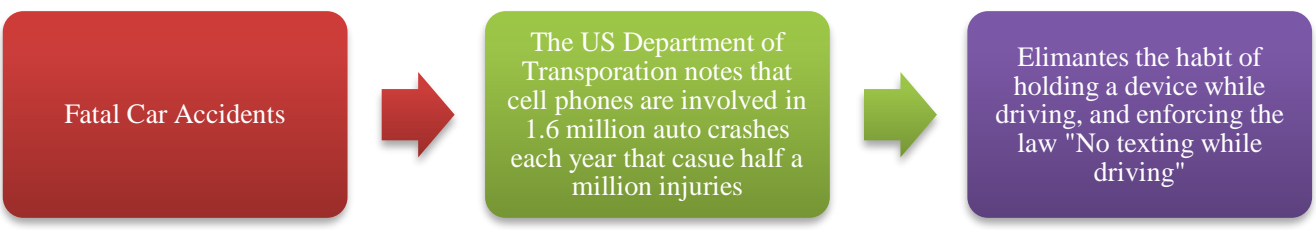

\section{Statistics}

Individuals who drive while sending or reading text messages are 23 times more likely to be involved in a car crash than other drivers. A crash typically happens within an average of three seconds after a driver is distracted.

\section{Further Studies}

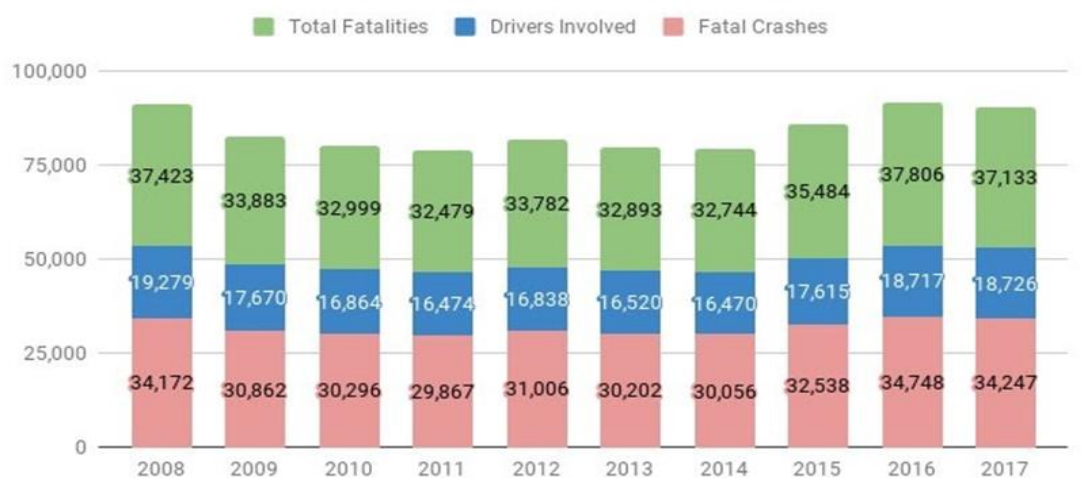

Figure 2. Fatal crashes 2008-2017 (Fatality Analysis Reporting Systems Encyclopedia)

Car accidents are one of the leading causes of death in the United States. Over the past decade, thousands of people have lost their lives in fatal car crashes due to device usage while driving. 


\section{Product Design}

Manufactured with sensor technology

95\% Polyester

- Water Resistance - Anti Sun damage

5\% Spandex

- Ability to stretch and take shape of any type of Wheel in the industry
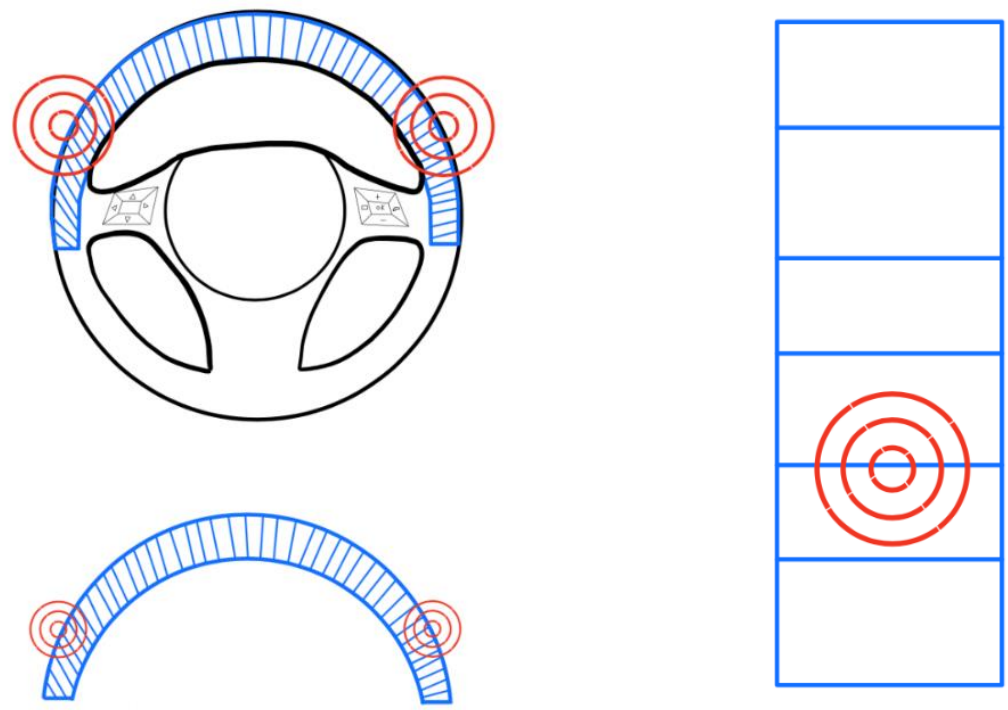

\section{Target Market \& Industry}

- Car Companies/Dealers

- New product to the market with added safety value to the vehicle

- Insurance Companies

- Lower chances of accidents

- Lower insurance rate when the product is added to the vehicle

- Car Rentals

- Lower rental rates when product is added to the vehicle due to lower chances of accidents

- Individuals

- Bought by or for beginners to eliminate the habit of holding a device when driving

Car Companies: Top 5 driven by profits and are willing to add an expense to their vehicles

- Toyota Motor Corporation: Topped the list with $\$ 17.5$ billion in net income for the year before Sept. 30, 2019. Toyota's profits were up slightly in the third quarter, driven by strength in Japan and North America. The firm expected to sell 8.95 million cars for its fiscal year ending March 31, 2020.

- Volkswagen: Posted approximately \$15.6 billion in profits for the year ending on Sept. 30, 2019.

- General Motors Company: Turned in profits of \$9.0 billion for the year ending September 30, 2019. General Motors managed to make over $\$ 3$ billion in pre-tax profits during the third quarter

- BMW: Produced a net income of $\$ 5.6$ billion in the year ending on Sept. 30, 2019.

- Honda Motor Company: Recorded \$4.8 billion in profits during the year before Sept. 30, 2019. 
Table 3. Insurance Companies: by Market Share

\begin{tabular}{|c|c|c|c|}
\hline Rank & Group/company & Direct premiums written (1) & Market share (2) \\
\hline 1 & State Farm Mutual Automobile Insurance & $\$ 65,861,617$ & $9.7 \%$ \\
\hline 2 & Berkshire Hathaway Inc. & $43,869,809$ & 6.5 \\
\hline 3 & Liberty Mutual & $34,605,081$ & 5.1 \\
\hline 4 & Progressive Corp. & $33,754,923$ & 5.0 \\
\hline 5 & Allstate Corp. & $33,251,176$ & 4.9 \\
\hline 6 & Travelers Companies Inc. & $26,244,172$ & 3.9 \\
\hline 7 & Chubb Ltd. & $22,125,338$ & 3.3 \\
\hline 8 & USAA Insurance Group & $21,984,970$ & 3.2 \\
\hline 9 & Farmers Insurance Group of Companies & $20,309,974$ & 3.0 \\
\hline 10 & Nationwide Mutual Group & $18,416,861$ & 2.7 \\
\hline
\end{tabular}

Research on the industry: How are the car safety gadgets doing? How are they selling?

Since the market does not have any similar products, I decided to look at car safety gadgets and consumers behaviour towards them.

\section{Automatic Connected Car Assistant}

- Crash Alert: 24/7 monitoring service that sends emergency services when a severe accident is detected. 3 Years Free.

- Car tracking: Real-time vehicle tracking, location sharing, parked car locator with notifications.

- Roadside Assistance: 24/7 Towing and roadside services delivered to you

- Driving History,

- Vehicle Diagnostics: Check engine light OBD 2 scan tool and code reader to help detect, decode and take the mystery out of your check engine light.

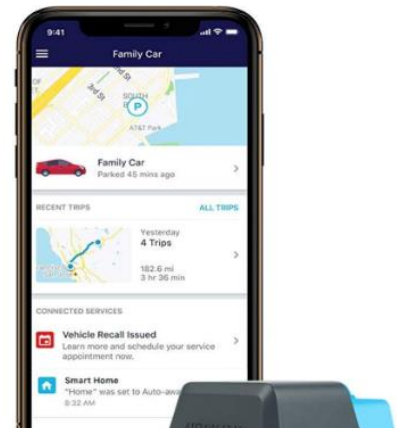

ZEEPIN Solar Power Universal, Wireless Tire Pressure Monitoring

- Dynamically monitors all tire pressure and temperature, improves fuel efficiency, and prolongs tire life and ensures driver safety.

- Fast Leak Alert: Easy to see big screen while driving, with a buzzer to alert the driver.

- Digital Screen: Bright backlist and clear readings

- Precision Direction System: 4 Sensors with waterproof and anti - corrosion, anti -theft technology, making it fully qualified for rainy days. High sensitivity, good accuracy for measuring pressure and temperature.

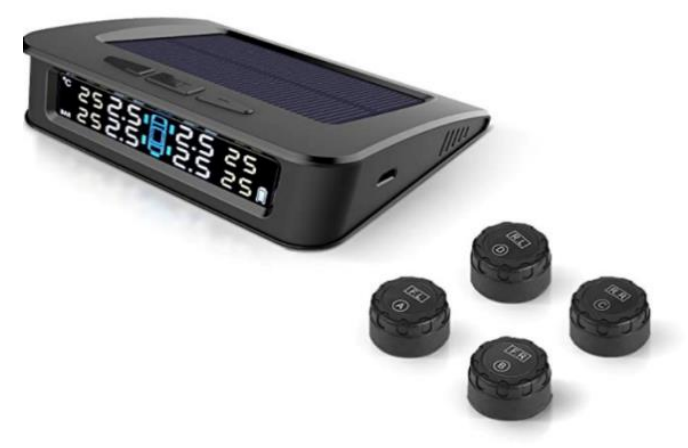

The Automatic Connected Car Assistant ranged from 88\$-160\$ while ZEEPIN ranged from 33\$-49\$, both products were doing well and were rated with 4-5 stars which depicts that the industry is successful and consumers are willing to pay anything between $90 \$$ to $160 \$$ for car safety gadgets, which allowed me to have an idea of how much SecureME should cost and how much I should sell it at. 
Table 4. Marketing 5 P's

\begin{tabular}{|c|c|c|c|c|}
\hline Product & Price & Promotion & Place & People \\
\hline $\begin{array}{l}\text { Includes a warranty } \\
\text { Available in multiple } \\
\text { colors } \\
\text { Use of polyester for } \\
\text { great quality } \\
\text { Neatly packaged }\end{array}$ & $\begin{array}{l}\text { Price around } 130-140 \$ \\
\text { (average price of safety } \\
\text { gadgets) }\end{array}$ & $\begin{array}{l}\text { Advertising: } \\
\text { introducing consumers } \\
\text { to the product by } \\
\text { explaining its features } \\
\text { whether on Podcasts, } \\
\text { videos on YouTube, } \\
\text { Instagram ad's }\end{array}$ & $\begin{array}{l}\text { Online website } \\
\text { Amazon } \\
\text { Car dealerships }\end{array}$ & $\begin{array}{l}\text { Sales representatives } \\
\text { Online chats for } \\
\text { customer services }\end{array}$ \\
\hline
\end{tabular}

\section{Manufacturer Business Model}

A manufacturer makes finished products from raw materials. It may sell directly to the customers or sell it to a middleman. I.e.: another business that sells it finally to the customer.

1. Core Strategy

- Business Mission

Our mission is your safety, by being accident free and both hands on the wheel. Stay Safe, Stay Secure with SecureME.

- Basis of Differentiation

The only safety device in the market to prevent accidents caused by device usage

Solves an ongoing trend with fewer accidents that cause injuries and deaths

- $\quad$ Target Market

Car companies driven by high profits that are willing to add an expense to their vehicles (Volkswagen, BMW, General Motors)

Insurance Companies, based of their market shares (State Farm, Liberty, Progressive)

- $\quad$ Product/Market Scope

Essentially, it will be marketed nationally to car companies but globally to individuals (through advertisements)

2. Resources

- $\quad$ Core Competency

There are no competitors in the market

Advantage of driving safely and being alerted from the habit of holding a device when driving

- Key Assets

Intellectual Assets: Patent

Financial assets: the ability to borrow without interests

Human Asset: a specialized team of engineers (Sensor technology), crafters (Leather), sales representatives (to advertise \& explain the product to consumers)

3. Financials

- $\quad$ Revenue Streams

Selling the products in bulk for both car companies and insurance companies

An individual online website

Creating multiple security gadgets for safety when driving (collection)

- $\quad$ Cost Structure

Engineer Costs

Leather crafters

Patent

The ability to sell at 130-140\$ (average price range of safety gadgets) with a low cost that could generate sufficient profits

- $\quad$ Financing/Funding

Onetime expense for the Website

Funds lent

4. Operations 
- $\quad$ Product Production

Specialized manufacturers in terms of the leather and sensors.

May be foreign or domestic manufacturers depending on the cost and quality

- Channels

The product can be sold directly from our website

The product can also be sold through car dealerships and insurance companies

- Key Partners

Progressive - Snapshot device

\section{Competitors}

Since the product is new to the market, there are no direct competitors.

Progressive Snapshot device is doing very well, the device comes along with an app, and if the driver has the app downloaded and holds the phone when driving the app can detect it with low accuracy. SecureME can actually compliment Snapshot where now there is an actual product that senses hands are not on the wheel, alerts, and maybe reveal the times of not holding the wheel correctly through the Snapshot app.

Since Amazon is the number one go to online shopping website, while doing the audit I have realized that the website has a page that features "Best Car Gadgets", where SecureME must compete to get on this page.

Aspects to legally protect

Patent (covers all aspects of the product from the leather, to the sensors within, and the idea behind it)

- Utility: New product to the industry, new in terms of material

- Design: First invention of a wheel cover with attached sensors within Trademark for the product's name

- Secure (ME), if I decided to expand, I am thinking of having the (ME) represent the company (For example another safety device that I would maybe name SensoreME)

Trade Secrets (the \% mix of material used for the leather) (sensor technology system)

- $\quad 95 \%$ Polyester: waterproof, sun resistant

- $5 \%$ Spandex: to create the right amount of stretch to fit every wheel in the industry.

\section{Legal Documents}

- Patent and Trademark Protection (register with the US Patent and Trademark office)

- License the product

- Sellers Permit

- Wholesalers' license

- Hire an attorney (Non-disclosure agreement for Trade Secrets)

\section{Corporation Name}

Option 1: SecureME DBA SensorME / Option 2: SensorME

\section{Legal Entity}

I have decided on an LLC.

1. The company is a start up

2. An LLC does not pay taxes (helpful since i am personally new to the industry)

3. Unlimited Shareholders

4. No double taxation

Due to being new to the industry with limited abilities and knowledge i see an LLC is the efficient choice. 


\section{CONCLUSION AND DISCUSSION}

This paper provided information on the main aspects of the business plan. There were highlighted the main benefits of a written business plan for the company and the readers, respectively its stakeholders. The components and their content were described in order to help practitioners to write 'winner' business plans. In order to make clearer to the readers, a practical example of a business plan was provided. The author provided an example of business plan, where is described the product which pretends to decrease car accidents. The sensor will sense that the drivers' hands are not on the wheel and will start to beep until the driver gets their hands back on the wheel. This is a challenge of a young entrepreneur to launch a new product and start an own business. Similar research, on students intentions are done by Permatasari and Agustina (2018), where they noted that "entrepreneurial intention is rooted in the vision, dreams and emotions of entrepreneurs and refers to a person's interest in striving to develop his/her own business and demonstrating the behaviour stemming from this desire" (p.96).

This paper was an attempt to convince the entrepreneurs that they must write a business plan in order to be more effective in managing of their businesses in one hand, and convince partners, creditors and investors that they are dedicated to their business and is worthy to invest in them.

\section{PRACTICAL IMPLICATIONS, LIMITATIONS AND FUTURE RESEARCH AVENUES}

This paper provides practical information for entrepreneurs on business planning, respectively for the role of business plan in effective business management. Besides theoretical information, in this paper is provided a sample case, which can help entrepreneurs and would-be entrepreneurs how to design and develop their business plans.

The limitations of this paper are related to the fact that it is based on only one single case and a specific sector. Other papers can take into consideration more business plans and ideas which might create a better and clearer picture to entrepreneurs about designing and developing comprehensive business plans. Also, would be good if other authors conduct research in their communities/countries in order to see whether their entrepreneurs have their own business plans, who writes them and how business pan helps them during the business activities.

\section{REFERENCES}

Anggadwita, G., \& Yuuhaa, Q. (2014). Identification of Factors Influencing the Performance of Small Medium Enterprises (SMEs), Procedia - Social and Behavioral Sciences, 115, 415-423

Burns, P., \& Dewhurst, J. (1990). Small Business and Entrepreneurship. Macmillan Education, Basingstoke. Byrd, J.M., \& Megginson, C.L. (2009) Small Business Management, 6th ed., McGraw-Hill/Irwin, Boston.

Cannon, J.A. (2006). Making the Business Case: How to Create, Write and Implement Business Plans, Making Chartered Institute of Personnel and Development, London.

Dana, L.P., \& Dana, T.E. (2005). Expanding the scope of methodologies used in entrepreneurship research', Int. J. Entrepreneurship and Small Business, 2(1), 79-88.

Entrepreneur Magazine (2020). Business Plan [online]. https://www.entrepreneur.com/encyclopedia/businessplan (Accessed 24 April 2020)

Genadinik, A. (2019). Business Plan Template and Example: How to Write a Business Plan: Business Planning Made Simple, Semantic Valley, New York.

Gumpert, E.D. (2000). How to Really Create a Successful Business Plan, $4^{\text {th }}$ ed., Lauson Publishing Company, Needham, MA,

Hisrich, R., \& Ramadani, V. (2017) Effective Entrepreneurial Management, Springer, Cham.

Hisrich, R., Peters, M., \& Shepherd, D. (2020) Entrepreneurship, $11^{\text {th }}$ ed., McGraw-Hill, New York.

Kuratko, F.D. (2020). Entrepreneurship: A Contemporary Approach, $11^{\text {th }}$ ed., Cengage Learning, Mason, OH.

Panthi, L. (2017). Example of business plan executive summary. In Hisrich, R. and Ramadani, V. Effective Entrepreneurial Management, Springer, Cham.

Permatasari, A., \& Agustina, A. (2018) Entrepreneurial Behavior among Undergraduate Business, Social and Engineering Students: A Case Study of a Private Indonesian University. Jurnal Manajemen Indonesia, 18(2), 94-104 
Scarborough, N., \& Cornwall, J. (2018). Essentials of Entrepreneurship and Small Business Management, 9th ed., Pearson, Essex.

Schwetje, G., \& Vaseghi, S. (2007). The Business Plan: How to Win Your Investors' Confidence, Springer, Heidelberg.

Utami, A.F., \& Triady, S. (2019). Understanding Attitude towards Change, Jurnal Manajemen Indonesia, 19(3), 210-215. 